\title{
Population size, distribution, threats and conservation status of two endangered bat species Craseonycteris thonglongyai and Hipposideros turpis
}

\author{
Sébastien J. Puechmaille ${ }^{1, *}$, Pipat Soisook $^{2}$, Medhi Yokubol $^{2}$, Piyathip Piyapan $^{2}$, \\ Meriadeg Ar Gouilh ${ }^{3,4}$, Khin Mie Mie ${ }^{5}$, Khin Khin Kyaw ${ }^{5}$, Iain Mackie ${ }^{6}$, \\ Sara Bumrungsri ${ }^{2}$, Ariya Dejtaradol ${ }^{2}$, Tin Nwe ${ }^{5}$, Si Si Hla Bu ${ }^{7}$, Chutamas Satasook ${ }^{2}$, \\ Paul J. Bates ${ }^{8}$, Emma C. Teeling ${ }^{1, *}$
}

\begin{abstract}
The population size, distribution, threats and conservation status of 2 bat species included as 'endangered' in the IUCN Red List were assessed in Thailand and Myanmar. Craseonycteris thonglongyai Hill, 1974 and Hipposideros turpis Bangs, 1901 are both rare and poorly known cave-dwelling species, which have restricted distributions and small population sizes. Surveys of the 2 species were conducted in a large number of locations including previously reported sites and potential new locations. Colony size was counted at currently known localities, and population size was estimated. The known distribution and population are larger than in previous estimates, but both species still remain threatened by roost disturbance and the destruction of foraging habitat. Clarification of the taxonomic status of allopatric populations within each species is urgently required.
\end{abstract}

KEY WORDS: Craseonycteris thonglongyai · Hipposideros turpis · Chiroptera · Endangered species · Distribution $\cdot$ Population size $\cdot$ Thailand $\cdot$ Myanmar

\section{INTRODUCTION}

South-East Asia includes 4 biodiversity hotspots, each containing exceptional animal and plant species diversity (Myers et al. 2000). Alarmingly, it is estimated that $42 \%$ of these species, many of which are endemic to those regions, could be extinct by 2100 (Sodhi et al. 2004, Sodhi \& Brook 2006). This 'worst case scenario' has already started in Singapore, where 881 species have been lost $(28 \%$ of the 3196 species covering a wide range of terrestrial and freshwater taxa), mainly due to anthropogenic changes, including deforestation, habitat degradation and overexploitation of plant and animal populations (Brook et al. 2003). A group of particular concern is the order Chiroptera, as it has been estimated that $67 \%$ of recently extant bat species have become extinct in Singapore (Lane et al. 2006). Small geographic ranges are considered the principal factor influencing extinction risks in bats (Jones et al. 2003). Therefore, species with a limited distribution are particularly vulnerable. With 121 bat species currently recorded in Thailand (Bumrungsri et al. 2006, Thong et 
al. 2006, Soisook et al. 2007), only 2 are classified as 'endangered' by the IUCN: Craseonycteris thonglongyai Hill, 1974 and Hipposideros turpis Bangs, 1901 (Chiroptera Specialist Group 1996), and both have a limited distribution and small population size.

Craseonycteris thonglongyai (Fig. 1) is the only known representative of the monospecific family, Craseonycteridae, which was discovered in 1973 by Kitti Thonglongya near Sai Yok, Kanchanaburi Province, Thailand (Hill 1974). At that time, about 50 caves were surveyed, but $C$. thonglongyai was only found in 2 of them (Duangkhae 1991). In 1980, the Royal Forestry Department declared $500 \mathrm{~km}^{2}$ of the area around the Sai Yok Waterfall as a national park. In the early 1980s, cave surveys were carried out in Kanchanaburi, but, unfortunately, the data concerning C. thonglongyai are very difficult to access. In some cases, the information has not been published; in others, it has been published as reports, including a number that were classified as confidential (see references in Duangkhae 1991). In 1991, Duangkhae reported the presence of $C$. thonglongyai in 21 out of 51 caves surveyed in Kanchanaburi and estimated the population size to be about 2000 (Duangkhae 1991). Since there were many unexplored caves at that time, Duangkhae (1991) suggested that the population size of $C$. thonglongyai could be as high as 300000 . Since this publication, no other study has been carried out relating to the population size and distribution of $C$. thonglongyai in Thailand. However, the discovery of a new population of about 1500 ind. in 9 localities in the states of Mon and Kayin, Myanmar, revealed that the C. thong-

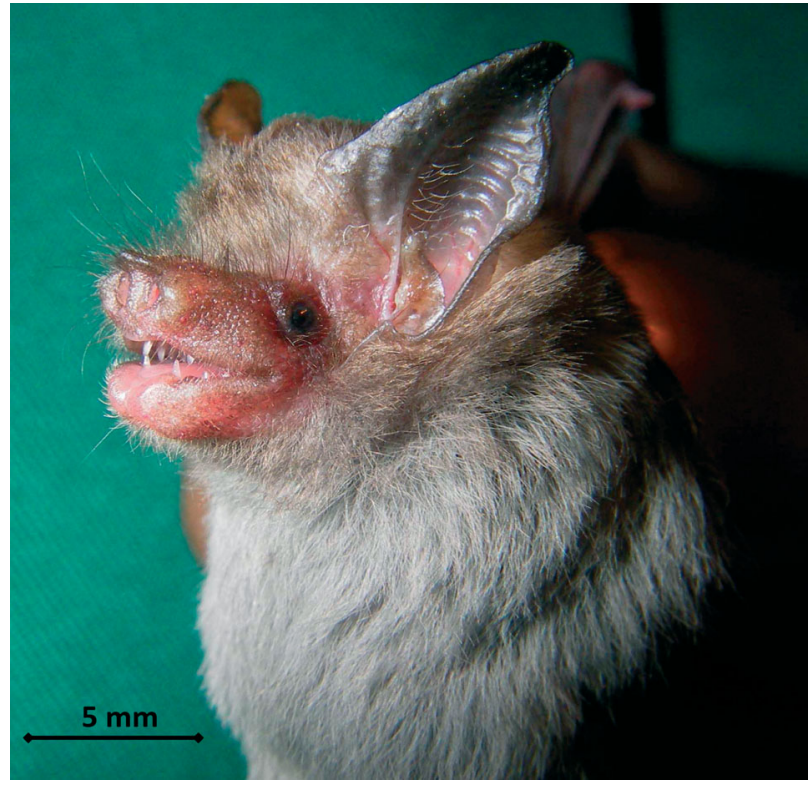

Fig. 1. Craseonycteris thonglongyai. Specimen from Myanmar longyai distribution was larger than previously thought (Bates et al. 2001, Ramos Pereira et al. 2006).

Hipposideros turpis (Fig. 2) was described from Ishigaki Island, Japan, and is currently known to be found on 4 Yaeyama (Shakishima) Islands, Japan (Abe 2005), in northern Vietnam and in peninsular Thailand (Simmons 2005). Two subspecies have been described; the nominate form $H$. $t$. turpis restricted to Japan, and $H$. $t$. pendleburyi Chasen, 1936 from Vietnam and Thailand (Corbet \& Hill 1992, Francis 2008). The global distribution of this species is quite disjunct, and its taxonomic status remains unclear (Borissenko \& Kruskop 2003, Francis 2008). In Thailand, its distribution was hitherto known from Khao Ram (i.e. Khao Ram Rome in Khao Luang National Park) in Nakhon Si Thammarat Province, where the taxon $H$. $t$. pendleburyi was described (Chasen 1936), and from Klong Wildlife Sanctuary (TISTR 1995) and other sites in Krabi Province (Lekagul \& McNeely 1977).

We report on the current distribution, population size and conservation status of Craseonycteris thonglongyai in Thailand and Myanmar and Hipposideros turpis in Thailand.

\section{MATERIALS AND METHODS}

Craseonycteris thonglongyai. Distribution: A series of field studies were carried out between 1997 and 2008, in which 181 caves were checked for the presence of $C$. thonglongyai (Fig. 3). In Thailand, cave surveys were focused mainly on Kanchanaburi Province

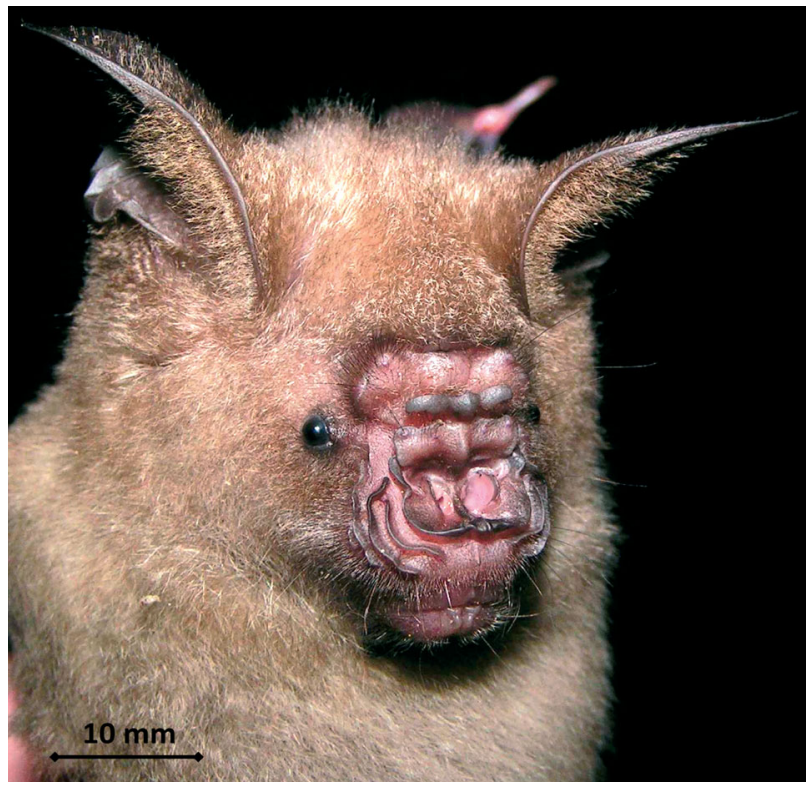

Fig. 2. Hipposideros turpis pendleburyi. Specimen from peninsular Thailand 


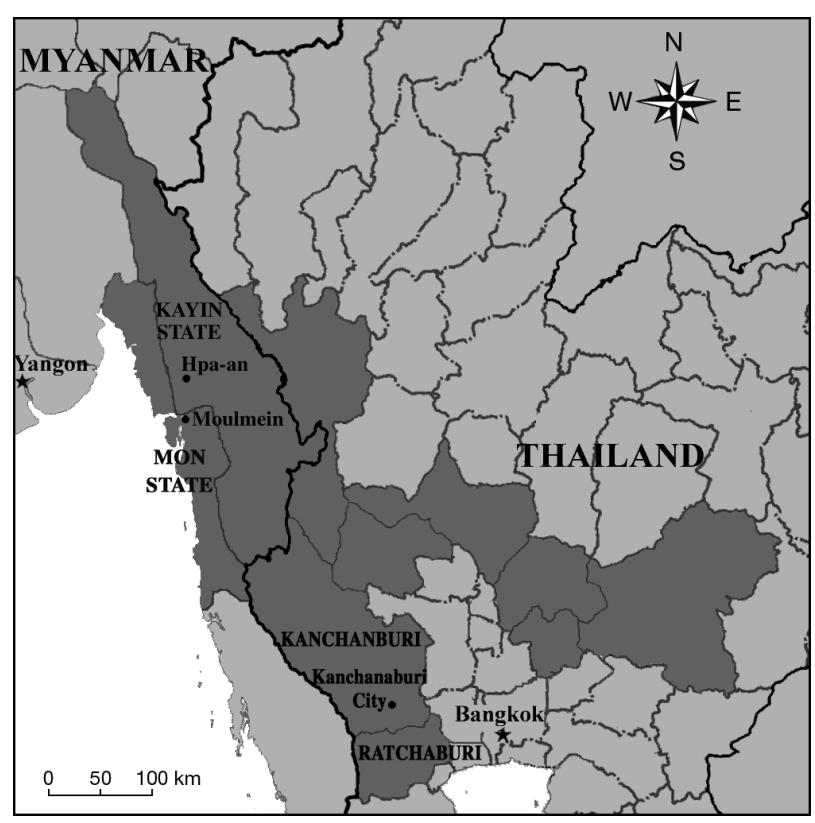

Fig. 3. Craseonycteris thonglongyai. Provinces and states surveyed for the presence of C. thonglongyai (dark grey areas) in Thailand and Myanmar

(112 localities), where the species was first discovered (Hill 1974). Caves were also surveyed in other provinces around the central plain (49 localities). These provinces were chosen because they included areas of limestone karst and climatic conditions (mean annual temperature from 26 to $28^{\circ} \mathrm{C}$ and rainfall from 800 to $2000 \mathrm{~mm}$ ) that were 'comparable' to those in Kanchanaburi, where the species had previously been described. In Myanmar, limestone outcrops around Mawlamyine (Moulmein) in the state of Mon and Hpaan in the state of Kayin were surveyed (20 localities) (Fig. 3). A more extensive survey outside the known distribution of the species was not possible for reasons of personal security.

The species was reported to be present if it was captured, or visually and acoustically identified inside the cave (Hill 1974, Surlykke et al. 1993). Acoustic identification of Craseonycteris thonglongyai was possible by distinguishing species-specific echolocation calls (Surlykke et al. 1993) via a heterodyne bat detector tuned at $75 \mathrm{kHz}$ (Pettersson D230) or via time-expanded recordings obtained with ultra-sound bat detectors (D-240X, D-1000X; Pettersson Elektronik $\mathrm{AB})$.

Population size: Colony size was estimated by 3 different methods. Most estimates were made by counting emerging individuals from cave entrances at dusk. This counting was feasible because of the early emergence of the species just after sunset and its typical flight pattern. When no emergence count was possible, C. thonglongyai were counted inside the cave or from photographs of the roosting colony. When $>1$ estimate was available for the same cave, only the most recent data were included in the analyses.

Counting bats, as outlined above, provides an estimate of colony size for the surveyed caves but not for the species as a whole, as many caves containing roosts are still unknown. Indeed, western and southern Thailand have the largest limestone area in the country, and there are many caves still to be surveyed (Sidisunthorn et al. 2006). However, by estimating the density of caves with roosts, the area of the species distribution and the average number of individuals per cave, it is possible to estimate the total population size of the species. As the precision of these estimates is dependent on the amount of data available (see 'Results'), we could only obtain a reliable population size estimate for Craseonycteris thonglongyai in Thailand.

To estimate the number of caves with Craseonycteris thonglongyai yet to be discovered in Kanchanaburi, we measured the area of the Sai Yok formation (Permian limestone) in this province. To be conservative, we excluded the limestone area around Srinakarin Dam, where no C. thonglongyai were found (see 'Results'). Geological maps of Thailand 1:250 000 (first edition in 1976, Accepted Reference Nos. ND47-6, ND47-11 and ND47-7) from the Geological Survey Division of the Department of Mineral Resources were digitised and areas were measured using tpsDig software V.2.10 (Rohlf 2004). The density of caves with $C$. thonglongyai was estimated from 2 reference areas (see area location in 'Results'; see Fig. 5) that have been well surveyed by our team (present study) and Duangkhae (1991). Next, the expected number of caves with $C$. thonglongyai was estimated by multiplying the total area by the cave density. The population size was then estimated by multiplying the estimated number of caves with roosts by the average colony size (the median and average colony size did not markedly differ).

Hipposideros turpis. Distribution: Between 2006 and 2008, a series of expeditions was conducted throughout Thailand by staff and students of Prince of Songkla University, Hat Yai. A total of 50 localities were surveyed in 10 provinces of peninsular Thailand, where $H$. turpis was first discovered. Another 67 localities were surveyed in 17 provinces between peninsular Thailand and Vietnam, where the species is also reported (Fig. 4).

Population size: Only direct counts within caves and photographic counts were undertaken for Hipposideros turpis. 


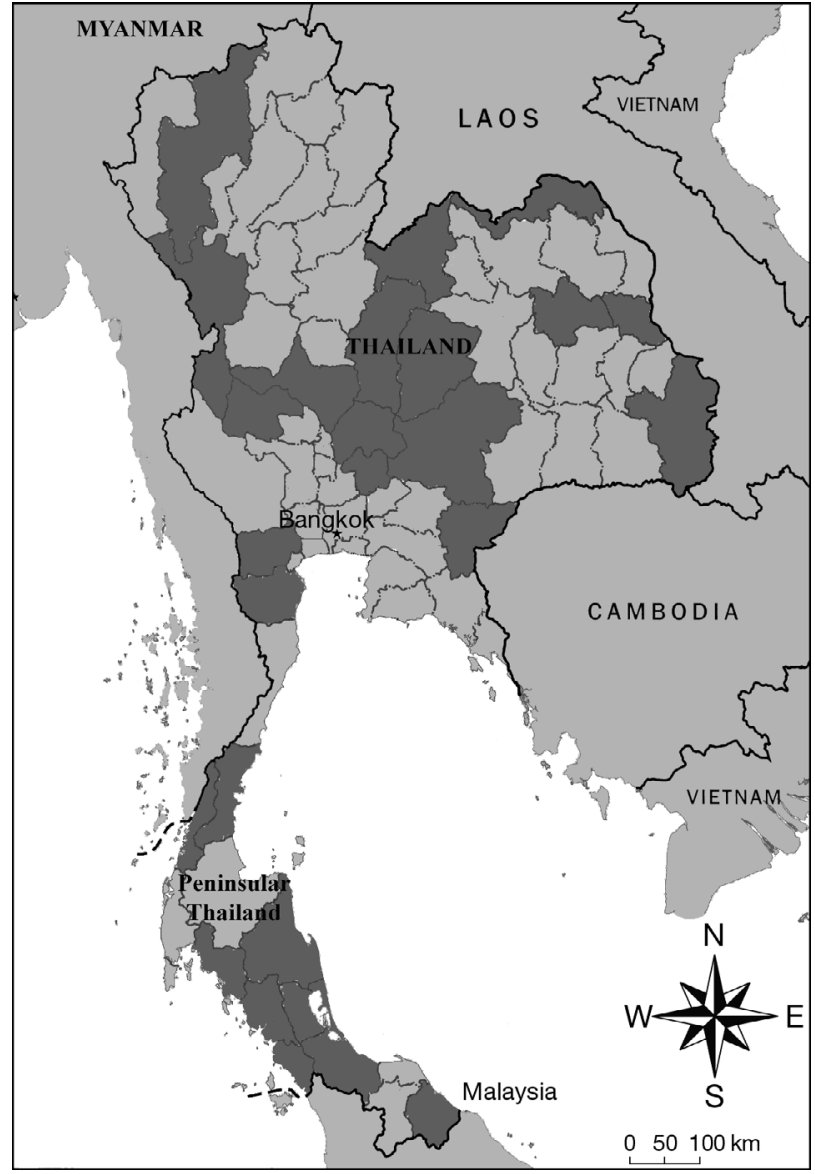

Fig. 4. Hipposideros turpis. Locations of the provinces surveyed for the presence of $H$. turpis (dark grey areas) throughout Thailand

\section{RESULTS \\ Craseonycteris thonglongyai}

\section{Distribution}

In total, 181 caves were surveyed, 20 in 2 Myanmar states and 161 in 10 provinces of Thailand. Craseonycteris thonglongyai was found in 49 caves, 44 in Thailand and 5 in Myanmar. Within its actual known distribution in Thailand, the species was present in $50 \%$ of the surveyed caves and in $25 \%$ in Myanmar. In Thailand, it was only found in Kanchanaburi Province from Kanchanaburi City in the southeastern part of the province, along the Kwae Noi River, up to Vajiralongkorn Dam (formerly known as Khao Laem Dam) in the northwestern part (Fig. 5). Current studies in Myanmar did not extend its known distribution, but did confirm its presence in 2 caves. Caves were generally surrounded by bamboo/ deciduous forest, temples, plantations (mainly Cassava; Manihot esculenta) in Thailand and rice fields in Myanmar. Exact geographic locations for the caves can be obtained upon request from the authors (S.J.P. \& E.C.T.) or the Prince of Songkla University Natural History Museum.

\section{Population size}

The census population size was 6487 in Thailand and 3770 in Myanmar. In Thailand, the average number of bats in each cave differed between counting methods. Averages of 73 and 74 bats were counted per cave via direct $(n=15)$ or photographic $(n=3)$ count, respectively. The average number of bats counted at emergence $(n=20)$ was 258 . For 6 caves where Craseonycteris thonglongyai were only heard via bat detectors, no estimates were available.

The 2 reference areas (110 and $80 \mathrm{~km}^{2}$; Fig. 5) contained 14 and 11 caves, respectively, sheltering

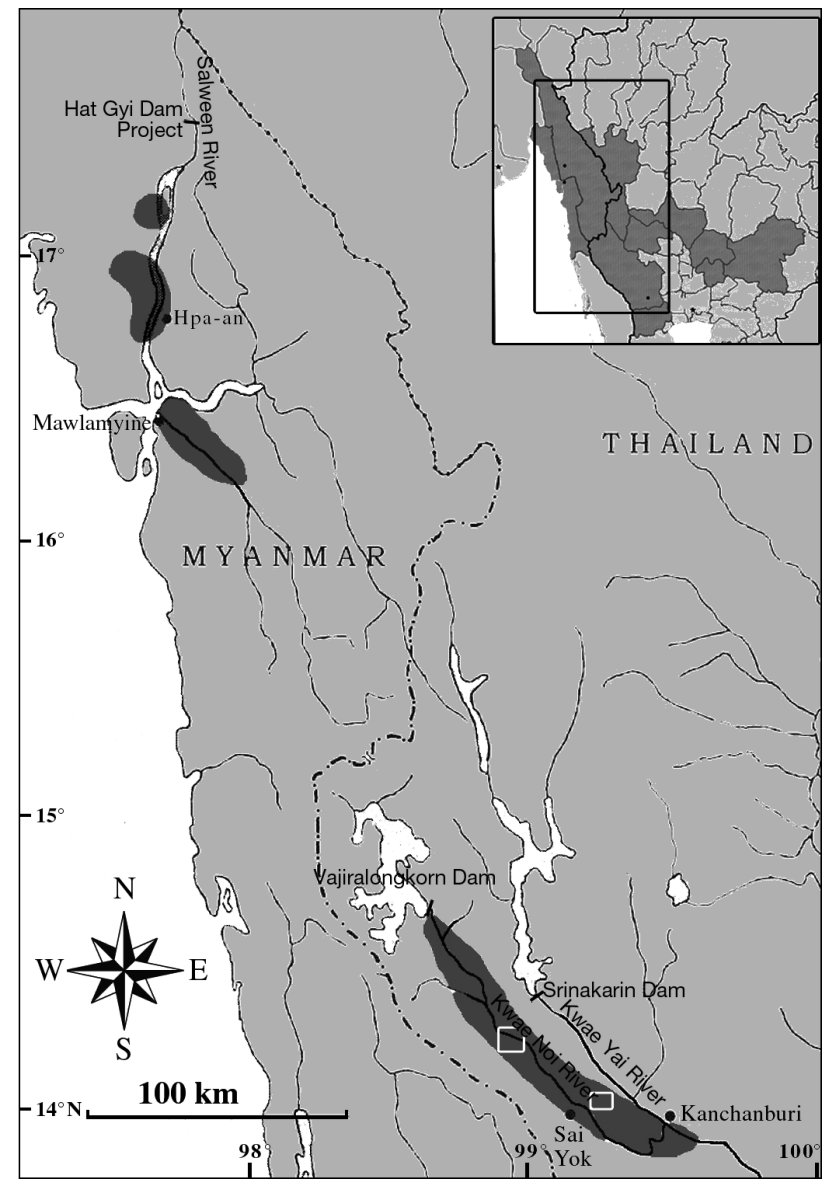

Fig. 5. Craseonycteris thonglongyai. Known distribution (dark grey areas) in Thailand and Myanmar. In Thailand, the 2 'reference areas' (see 'Materials and methods') are mapped as rectangles 
Craseonycteris thonglongyai, which corresponds to an average of 1 cave every $7.6 \mathrm{~km}^{2}$. The total surface of limestone (Sai Yok formation) within the known distribution of $C$. thonglongyai is $1312 \mathrm{~km}^{2}$. The number of caves sheltering the species is estimated to be ca. $173(1312 / 7.6)$ caves. As emergence counts were the most reliable estimate of colony size (see 'Discussion'), we only used these data to estimate the total population size in Thailand (ca. 45000 [173 $\times$ 258] ind.).

\section{Hipposideros turpis}

\section{Distribution}

Of the 117 localities visited, the species was found at only 8 localities in 3 provinces of peninsular Thailand: Krabi, Trang and Nakhon Si Thammarat (Fig. 6). Six were in 3 districts of Krabi Province, with only 1 locality in each of the other 2 provinces. All localities were in limestone outcrops, mainly surrounded by rubber plantations (Hevea brasiliensis), oil palm plantations (Elaeis guineensis), temples and villages (Table 1).

\section{Population size}

Currently, the known population size of Hipposideros turpis in peninsular Thailand slightly exceeds 1400 ind. (Table 1). About 60\% was found in Krabi Province, where the species was observed in 4 caves and captured at 2 sites in the forest using harp-traps. The other $40 \%$ was found in Nakhon Si Thammarat and Trang Provinces, with 350 ind. at the Khao Daeng cave and 190 ind. at the Rad cave. Females were pregnant in late March at Thanbok Koranee National Park and lactating in early May at the Khao Daeng cave, but we only counted adults.

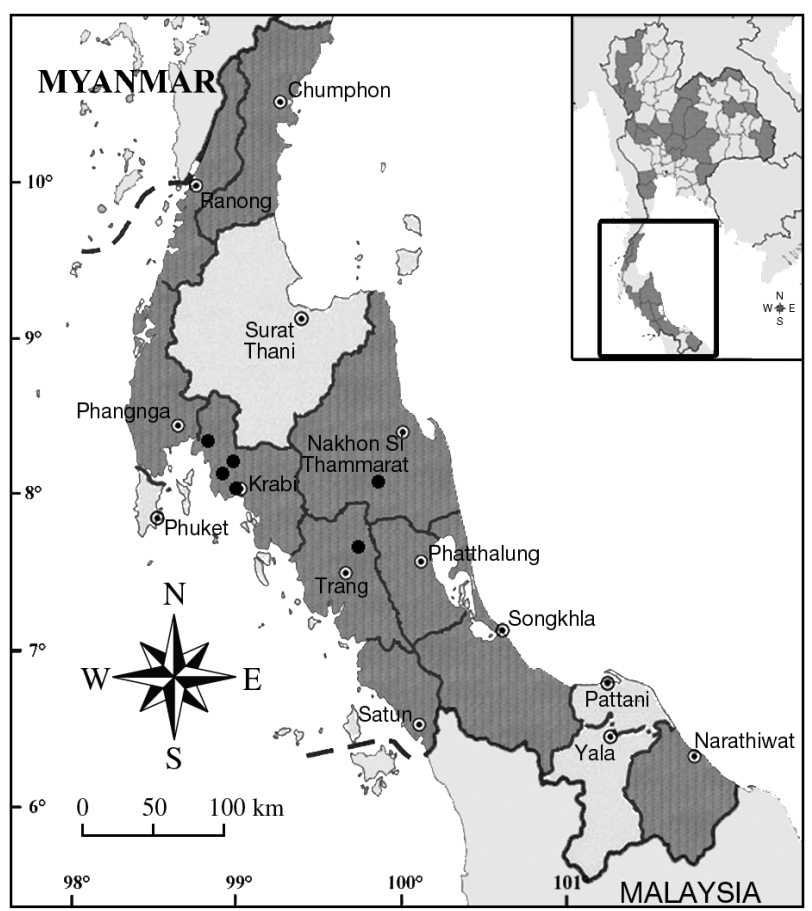

Fig. 6. Hipposideros turpis. Localisation of the sites (0) where the species has been found in peninsular Thailand. In Krabi Province, the northernmost dot represents 3 sites in Thanbok Koranee National Park

\section{DISCUSSION}

\section{Craseonycteris thonglongyai}

Distribution

For nearly $20 \mathrm{yr}$, Craseonycteris thonglongyai was thought to be restricted to a few caves in and around the Sai Yok National Park (Duangkhae 1991). In 2001, the discovery of a population in Myanmar (Bates et al.

Table 1. Hipposideros turpis. Number of individuals, surrounding habitats and threats to known sites of $H$. turpis in peninsular Thailand. NP: National Park

\begin{tabular}{|lcll|}
\hline Sites & $\begin{array}{c}\text { No. of } \\
\text { individuals }\end{array}$ & Surrounding habitat & Threats \\
\hline Khao Kanab Nam, Krabi & 4 & Mangrove forest & - \\
Khao Phanombenja NP, Krabi & 350 & Oil palm plantation & - \\
Sang Phet cave, Krabi & 100 & Rubber plantation, monastery, villages & Habitat degradation \\
Khao Rang, Krabi & 40 & Oil palm plantation & Habitat degradation, roost \\
& & & disturbance \\
Khao Phra cave, Krabi & 350 & Oil palm plantation, temple & - \\
Nature trail (Thanbok Koranee NP), Krabi & 18 & Evergreen forest & Habitat degradation \\
Rad cave, Trang & 190 & Rubber plantation & Habitat degradation, roost \\
Khao Daeng cave, Nakhon Si Thammarat & 350 & Rubber plantation, temple, villages & disturbance \\
& & &
\end{tabular}


2001) suggested that its very limited known distribution might also, in part, be a reflection of a lack of detailed survey work.

In the present study, we surveyed 161 caves in 10 different provinces of Thailand, but were unable to find Craseonycteris thonglongyai outside the Kanchanaburi Province. It is very difficult to prove the absence of a species in a particular location, but our surveys show that, if the species is present outside of Kanchanaburi, it is far less abundant. The species is present in over half of surveyed caves around the Kwae Noi River valley, Kanchanaburi. In addition, other researchers have surveyed many caves throughout Thailand (Bumrungsri et al. 2006, S. Bumrungsri et al. unpubl. data), and none have reported the presence of the species outside Kanchanaburi, suggesting that its presence there is unlikely. For example, 18 caves were surveyed in Ratchaburi Province, 30 to $50 \mathrm{~km}$ south of the nearest known locality of $C$. thonglongyai, but, despite the geographic proximity, the species was not found.

Duangkhae (1991) reported 21 caves with Craseonycteris thonglongyai, 13 of which were not visited during our survey. Therefore, the total number of caves where the species has been found in Thailand is 57 . In Kanchanaburi Province, the actual distribution of $C$. thonglongyai is about 3 times larger in area $(145 \mathrm{~km}$ long and 10 to $15 \mathrm{~km}$ wide) than the assumed distribution based on previous published data (Duangkhae 1991). The species appears to be absent from the area surrounding the Srinakarin Dam, where $>15$ caves were surveyed. This absence is surprising as this limestone area is only a few kilometres from the main limestone block. However, the Sai Yok formation is divided into 2 categories: 'limestone, massive, with chert nodules and fusulinids', where $C$. thonglongyai was found, and 'limestone, gray to light gray, bedded, locally reef, with chert nodules; and sandstone', where the species was not found (see Geological Map ND47-6). These geological differences might explain the absence of $C$. thonglongyai. The same is to be reported around Vajiralongkorn Dam in the north. C. thonglongyai is present $2 \mathrm{~km}$ south of the dam in the Sai Yok formation, but was not found by Duangkhae (1991), who surveyed caves from a different geological period (Jurassic-Triassic vs. Permian) just a few kilometres north of the dam. Caves in different rock categories could have a different microclimate and/or configuration due to the influence of rock properties on cave formation (Palmer 2007). A further study on climatic variation between caves from different rock categories within the distribution range of this species is recommended. The influences of climate and other environmental or biotic factors on the presence or absence of C. thonglongyai need to be further investigated.
Population size

Different methods were used to count Craseonycteris thonglongyai, and as the counting method was not chosen according to the colony size (which was not known a priori), the average number of bats per cave should theoretically be comparable for the different methods. It is clear that emergence counts were higher than photographic and direct counts. This difference could either reflect an overestimate of the emergence count method or an underestimate of the photographic and direct count methods or both. For some caves, emergence counts were carried out independently by 2 different people at the same time and furnished similar results (data not shown). Additionally, colony size counted when bats were returning to the cave in the early morning furnished similar results to emergence counts carried out in the previous or following evening (data not shown). For these reasons, emergence counts are believed to furnish reliable estimates of $C$. thonglongyai colony size. Since $C$. thonglongyai often roosts in small chambers, small crevices, or small holes that are difficult to access, photographic and direct counts usually underestimate colony size. As an example, in 4 out of the 5 caves sheltering $C$. thonglongyai in Myanmar, not a single individual was seen or recorded inside the cave during the day, but they were observed flying out at emergence time, emphasizing the validity of emergence counts compared to direct or photographic counts. As a result, photographic and direct counts can be regarded as minimum estimates in a rapid assessment of bat populations, whereas emergence counts can be considered the most reliable colony size estimate.

Considering only emergence counts, $80 \%$ of the colonies in Thailand included between 100 and 400 ind. ( $\mathrm{n}=20$, range $=11$ to 856 ). In Myanmar, emergence counts at 4 caves furnished estimates of 40,600 , 1100 and 2000 ind. Even if the number of caves surveyed is low, it seems that colony size is much larger in Myanmar than in Thailand.

The known number of Craseonycteris thonglongyai, 6487 in Thailand and 3770 in Myanmar, probably represents only a fraction of the actual species population size, as it is likely that many caves containing roosts have not been surveyed. Considering the density of known caves with the species present (1 every 7.6 $\mathrm{km}^{2}$ ), the average number of individuals per cave (258) and the area of the limestone block where the species is present $\left(1312 \mathrm{~km}^{2}\right)$, the total population size of the species in Kanchanaburi, Thailand, can be estimated at around 45000 ind. However, this figure probably underestimates the true population size for 2 reasons: (1) because the cave density is underestimated, since there are difficulties in finding caves owing to the 
scarp topography and dense vegetation; and, (2) only the area of limestone in the Sai Yok formation was considered, whereas some caves with $C$. thonglongyai have been found in zones described as Quaternary deposits. In these latter areas, the deposit layer is thin (see the geological cross section on Map ND47-7) and limestone pockets with caves are present, but are not represented on the map due to their small size. Thus, the estimate is conservative and should be regarded as a minimum population size.

The same estimates could be calculated for Myanmar, but we would need more data regarding the Craseonycteris thonglongyai distribution, the density of caves with roosts and the average colony size. Considering the large area of Permian limestone in the states of Mon and Kayin (1684 km² with 137 outcrops; calculated after Earth Sciences Research Division 1977) and the relatively large average colony size (935 ind. cave $^{-1}$ ), it would not be surprising if the Myanmar population was in excess of 100000 ind. However, more surveys are essential to obtain a reliable estimate for the Myanmar population.

\section{Taxonomic status}

The taxonomic status of the 2 populations in Thailand and Myanmar has yet to be resolved as the large difference in peak frequency of the echolocation calls suggests that each population may have been isolated for some time (Surlykke et al. 1993, Ramos Pereira et al. 2006). A thorough study of the genetic diversity, divergence and isolation of these populations is critical to establish the taxonomic status of each population.

Threats, conservation status and recommendations

Human disturbance by tourists and pilgrims is a considerable threat to Craseonycteris thonglongyai populations in Thailand (Yokubol 2000) and may become a problem in Myanmar if the caves begin to attract more people. Studying the roosting selection of the species is required as it would enable us to predict suitable roosting sites for $C$. thonglongyai. This would serve to establish conservation priorities in order to inform cave management guidelines in relation to human access/disturbance. In Thailand, another major threat is habitat destruction through deforestation and forest burning, which reduces suitable foraging habitats for the species (Yokubol 2000). A detailed study on foraging habitat quality is immediately needed to investigate what factors determine a good foraging site for the species. Another concern is the killing of individuals through hunting as a source of food (Yokubol 2000).
In Myanmar, the construction of a dam on the Salween River and the development of a limestone mining industry could rapidly become major threats to $C$. thonglongyai (Ramos Pereira et al. 2006, Ngyeh 2007).

The status of Craseonycteris thonglongyai was last assessed as 'endangered' (EN B1 + 2c, C2b; Ver. 2.3) by the IUCN in 1996. This is now considered to be out of date (Chiroptera Specialist Group 1996). Since the 1996 assessment, a new population has been found in Myanmar (Bates et al. 2001), and the population size and distribution has been extended in Thailand (present study). These new data will provide important additional information for a revision of its status. However, there are some aspects that still require further investigation.

Habitat loss/degradation through deforestation near caves directly affects Craseonycteris thonglongyai by reducing its foraging sites (Yokubol 2000), but the long-term impact of this habitat change in terms of population fragmentation is not known and would deserve particular attention.

Despite our efforts, the distribution and population size of Craseonycteris thonglongyai in Myanmar are still poorly known. Cave surveys need to be carried out more extensively in the states of Mon and Kayin, especially in the area of the dam construction where $C$. thonglongyai could be present.

For Thailand and Myanmar, the population trend of Craseonycteris thonglongyai is difficult to assess at the moment because of the limited data available and the difficulty in comparing estimates carried out using different methods or at different periods of the year (Yokubol 2000, Yokubol et al. 2006, S. Puechmaille unpubl. data). Monitoring schemes need to be launched, possibly including emergence counts and/or walking or driving transects similar to the iBat monitoring program (see www.ibats.org.uk/).

\section{Hipposideros turpis}

\section{Distribution and population size}

The species distribution in Thailand is quite small and restricted to 3 provinces, Krabi, Nakhon Si Thammarat and Trang, where its presence is restricted to limestone outcrops. Within this distribution, it appears to be restricted to 4 main areas, which are located between 30 and $130 \mathrm{~km}$ from each other. This suggests that either the species is very rare or many caves with roosts are still unknown. The actual known population size is quite small, so each cave and its surroundings are important. This is especially the case in Khao Phanombenja National Park and in Khao Phra and Khao Daeng caves, which are the roosts for threefourths of the known population. 


\section{Taxonomic status}

Hipposideros turpis pendleburyi is very similar to $H$. armiger, but differs in its smaller size and the presence of only 3 supplementary leaflets in the nose-leaf (Chasen 1936, Lekagul \& McNeely 1977) (see Fig. 2). The 2 species were found sympatrically in Khao Phra cave, Krabi. The specimens of $H$. turpis from peninsular Thailand, referred to H. t. pendleburyi, are considerably larger than the nominate subspecies (Lekagul \& McNeely 1977). Borissenko \& Kruskop (2003) reported that the Vietnamese form seems to correspond with the description of $H$. $t$. pendleburyi from peninsular Thailand. Specimens from Vietnam referred to $H$. turpis were initially described as a subspecies of $H$. larvatus, namely $H$. 1. alongensis Bourret, 1942. Based on cranial measurements only, $H$. l. alongensis was reclassified as H. turpis alongensis (Topál 1993), although externally, individuals look like $H$. larvatus. Photographs of $H$. turpis from Vietnam (Hendrichsen et al. 2001, Hutson et al. 2001, S. Puechmaille pers. obs.) clearly resemble $H$. larvatus and not $H$. turpis. According to the average forearm length $(71.7 \mathrm{~mm})$ (Hendrichsen et al. 2001), individuals from Vietnam are smaller than those in peninsular Thailand (mean $=77.8 \mathrm{~mm}, 75.2$ to 80.8 $\mathrm{mm}, \mathrm{SD}=1.7, \mathrm{n}=11$ ). Moreover, their echolocation call frequency is much lower at around $72 \mathrm{kHz}(\mathrm{n}=1$; $\mathrm{S}$. Puechmaille unpubl. data) compared to $85.9 \mathrm{kHz}(83.8$ to $87.2 \mathrm{kHz}, \mathrm{SD}=1.2, \mathrm{n}=23$ ) in peninsular Thailand ( $\mathrm{P}$. Soisook unpubl. data). The systematic status of $H$. turpis and the different subspecies remains very unclear in view of the unusual distribution (Hutson et al. 2001), the differences in nose-leaf morphology, size and echolocation call frequency. Further taxonomic studies of the disjunct populations of $H$. turpis are a priority. Echolocation and molecular data may prove that $H$. turpis populations from Japan, Vietnam and Thailand are not conspecific, and the taxa $H$. t. pendleburyi and $H$. $t$. alongensis may prove to be specifically distinct and endemic to peninsular Thailand and Vietnam, respectively.

\section{Threats, conservation status and recommendations}

Most of the known localities for the species are outside protected areas, and here their foraging habitats have been severely degraded. There has been a recent and rapid conversion of land to agricultural use. In the Thanbok Koranee National Park, where the largest population of Hipposideros turpis is known to exist, only the limestone outcrops are included in the park area. The surrounding habitats have been converted to oil palm and rubber plantations and to urban areas. Therefore, the habitat around the roosting sites of these populations is now fragmented. The future of the population at Khao Daeng cave, another large colony, is uncertain, as the Khao Daeng outcrop is being considered for limestone mining and quarrying. $H$. turpis should be monitored by directly counting the number of individuals in every cave where the species is known to roost.

The status of Hipposideros turpis was last assessed as 'endangered' (EN A2c; Ver. 2.3) by the IUCN in 1996 (Chiroptera Specialist Group 1996). This listing is now considered out of date. When the species was previously assessed, there was no information on its population status or the threats to it in Thailand and Vietnam (Hutson et al. 2001). The data presented here will help to re-evaluate the status of the species for the population present in peninsular Thailand.

\section{CONCLUSIONS}

Craseonycteris thonglongyai and Hipposideros turpis are 2 cave-dwelling species with limited distributions in limestone areas. Their conservation requires the protection of their roosts and foraging habitats. The main threats for caves are quarrying, which would destroy roosts, and human disturbance. Foraging habitats are threatened by fragmentation and destruction.

For both species, the taxonomic status of each population should be clarified: Craseonycteris thonglongyai, with populations in Thailand and Myanmar, and Hipposideros turpis, with populations in Japan, Vietnam and Thailand. This should be done in connection with more cave surveys, allowing more precise estimations of distribution and population size for each species.

Acknowledgements. We are grateful to employees at Sai Yok and Erawan National Parks, Thailand, for assisting us during the Craseonycteris survey and at Thanbok Koranee National Park for helping us during the survey of the Andaman World Heritage Project. Thanks to Tuanjit Srithongchuay, Bounsavane Douangboubpha, Phansamai Phommexay and all staff and students in the PSU Bat Research Unit for their help in the field. Thanks to the Biodiversity Research and Training Program, Thailand, and Bat Conservation International for their financial support. We also thank the Wildlife Fund Thailand for their support during our project. Thanks to the IRD UR 178, Mahidol University, for their logistic support during fieldwork in Thailand. Thanks to Nu Nu Aye, Wai Wai Myint, Aye Thida and Thida Tin, who greatly helped in the field in Myanmar. We are indebted to Vu Dinh Thong and Neil Furey, who co-ordinated the surveys in Cat Ba and Ba Be National Parks, Vietnam. We thank Sumiko Matsumura (Japan) for the loan of specimens of Hipposideros turpis. We thank the staff at the World Bat library (Geneva, Switzerland) for kindly providing us with references. Thanks to Fabio Bontadina and 3 anonymous reviewers for comments on the manuscript. We thank the Darwin Initiative (DEFRA, UK) The Royal Society (Inter- 
national project, UK), the Science Foundation Ireland (RFP GEN0056) and the Royal Irish Academy for their financial support of this project.

\section{LITERATURE CITED}

Abe H (2005) A guide of the mammals of Japan. Tokai University Press, Tokyo

Bates PJJ, Nwe T, Swe KM, Hla Bu SS (2001) Further new records of bats from Myanmar (Burma) including Craseonycteris thonglongyai Hill, 1974 (Chiroptera: Craseonycteridae). Acta Chiropt 3:33-41

Borissenko AV, Kruskop SV (2003) Bats of Vietnam and adjacent territories: an identification manual. Joint RussianVietnamese Science and Technological Centre and Zoological Museum of Moscow. MV Lomonsov State University, Moscow

Brook BW, Sodhi NS, Ng PKL (2003) Catastrophic extinctions follow deforestation in Singapore. Nature 424: 420-423

Bumrungsri S, Harrison DL, Satasook C, Prajukjitr A, ThongAree S, Bates PJJ (2006) A review of bat research in Thailand with eight new species records for the country. Acta Chiropt 8:325-359

Chasen FN (1936) New and noteworthy bats from the Malay Peninsula. Bull Raffles Mus 12:133-134

Chiroptera Specialist Group (1996) Craseonycteris thonglongyai. In: 2007 IUCN Red List of threatened species. Available at: www.iucnredlist.org/ (downloaded on 20 May 2008)

Corbet GB, Hill JE (1992) The mammals of the Indomalayan region. Natural History Museum and OUP Press, Oxford

Duangkhae S (1991) Search for Kitti's hog-nosed bat Craseonycteris thonglongyai in western Thailand. Nat Hist Bull Siam Soc 39:1-17

Earth Sciences Research Division (1977) Geological map of the Socialist Republic of the Union of Burma, Rangoon, 1:1 000 000. Dept. of Geological Survey and Exploration, Rangoon

Francis CM (2008) Field guide to mammals of Thailand and South-East Asia. Asia Books, Bangkok

Hendrichsen DK, Bates PJJ, Hayes BD, Waltson JL (2001) Recent records of bats (Mammalia: Chiroptera) from Vietnam with six species new to the country. Myotis 39:35-122

Hill JE (1974) A new family, genus and species of bat (Mammalia: Chiroptera) from Thailand. Bull Br Mus (Nat Hist) Zool 27:301-336

Hutson AM, Mickleburgh SP, Racey PA (2001) Microchiropteran bats: global status survey and conservation action plan. IUCN, Gland and Cambridge

Jones KE, Purvis A, Gittleman JL (2003) Biological correlates of extinction risk in bats. Am Nat 161:601-614

Lane DJW, Kingston T, Lee BPYH (2006) Dramatic decline in bat species richness in Singapore, with implications for Southeast Asia. Biol Conserv 131:584-593

Lekagul B, McNeely JA (1977) Mammals of Thailand.

Editorial responsibility: Fiona Mathews,

Exeter, UK
Sahakarnbhat, Bangkok

Myers N, Mittermeier RA, Mittermeier CG, da Fonseca GAB, Kent J (2000) Biodiversity hotspots for conservation priorities. Nature 403:853-858

Ngyeh A (2007) Karenni forests, heart of its people, destroyed to prepare for Wei Gyi Dam construction. Salween Watch Newsletter 1:4

Palmer AN (2007) Cave geology. Cave Books, Dayton

> Ramos Pereira MJ, Rebelo H, Teeling EC, O'Brien SJ and others (2006) Conservation of the world's smallest mammal, the bumble-bee bat Craseonycteris thonglongyai, in Myanmar. Oryx 40:456-463

Rohlf FJ (2004) tpsDig, digitize landmarks and outlines, Version 2.10. Department of Ecology and Evolution, State University of New York, Stony Brook

Sidisunthorn P, Gardner S, Smart D (2006) Caves of northern Thailand. River Books, Bangkok

Simmons NB (2005) Order Chiroptera. In: Wilson DE, Reeder DM (eds) Mammal species of the world: a taxonomic and geographic reference. Johns Hopkins University Press, Baltimore, MD, p 312-529

Sodhi NS, Brook BW (2006) Southeast Asian biodiversity in crisis. Cambridge University Press, Cambridge

Sodhi NS, Koh LP, Brook BW, Ng PKL (2004) Southeast Asian biodiversity: an impending disaster. Trends Ecol Evol 19: $654-660$

Soisook P, Bumrungsri S, Dejtaradol A, Francis CM, Csorba G, Guillén-Servent A, Bates PJJ (2007) First records of Kerivoula kachinensis (Chiroptera: Vespertilionidae) from Cambodia, Lao PDR and Thailand. Acta Chiropt 9: 339-345

Surlykke A, Miller LA, Møhl B, Andersen BB, Christensen-Dalsgaard J, Jørgensen MB (1993) Echolocation in two very small bats from Thailand: Craseonycteris thonglongyai and Myotis siligorensis. Behav Ecol Sociobiol 33: 1-12

Thong VD, Bumrungsri S, Harrison DL, Pearch MJ, Helgen KM, Bates PJJ (2006) New records of Microchiroptera (Rhinolophidae and Kerivoulinae) from Vietnam and Thailand. Acta Chiropt 8:83-93

TISTR (Thailand Institute of Scientific Technological Research) (1995) The master plan for Klong Phraya Wildlife Sanctuary, Surat Thani Province. TISTR, Bangkok (in Thai)

Topál G (1993) Taxonomic status of Hipposideros larvatus alongensis Bourret, 1942 and occurrence of $H$. turpis Bangs, 1901 in Vietnam (Mammalia, Chiroptera). Acta Zool Hung 39:267-288

Yokubol M (2000) Habitat use and the population trend of Kitti's hog-nosed bats (Craseonycteris thonglongyai) in disturbed habitats in western Thailand. Master's thesis (Environmental Biology), Faculty of Graduate Studies, Mahidol University, Bangkok

Yokubol M, Piyapan P, Duangkhae S (2006) Distribution, population trend, and threats of Kitti's hog-nosed bat (Craseonycteris Thonglongyai) in Thailand. J Wildlife Thai 13:61-73 (in Thai)

Submitted: June 11, 2008; Accepted: October 6, 2008

Proofs received from author(s): February 11, 2009 